\section{Dental Pulp Fibroblas ts Response after Stimulation with HEMA and Adhesive System}

Karin Cristina da Silva Modena ${ }^{1}$, Adriana Maria Calvo², Carla Renata Sipert ${ }^{3}$, Thiago José Dionísio ${ }^{2}$, Maria Fidela de Lima Navarro ${ }^{1}$, Maria Teresa Atta ${ }^{1}$ Carlos Ferreira Santos ${ }^{2}$

\begin{abstract}
This study evaluated in vitro cell viability and metabolism, nitric oxide release and production of chemokines by cultured human dental pulp fibroblasts (DPF) under contact with HEMA and Single Bond. Cultures of DPF were established by means of an explant technique. Once plated, cells were kept under contact with increasing concentrations of HEMA (10, 100 and $1000 \mathrm{nM})$ or Single Bond (SB) [10-fold serially diluted in culture medium $\left(10^{-4}, 10^{-3}\right.$ and $\left.\left.10^{-2} \mathrm{v} / \mathrm{v}\right)\right]$ and also with polymerized SB components. Cytotoxicity was assessed by Trypan Blue exclusion method and MTT [3-(4,5-Dimethylthiazol-2-yl)2,5-diphenyltetrazolium bromide] assay. Nitric oxide release on cell supernatant was detected by Griess Method whereas chemokines (CXCL12 and CXCL8) were detected by ELISA. RT-qPCR was employed for chemokines gene expression analysis. Cytotoxic tests showed significant differences for SB $10^{-2}$. None of the tested materials significantly altered NO levels. Protein levels of CXCL12 were significantly decreased only by HEMA. On the other hand, while CXCL12 mRNA remained unaltered, gene expression of CXCL8 had significant decrease with all materials, except for polymerized SB. In conclusion, Single Bond and HEMA at various concentrations, decreased expression and production of molecules involved in inflammatory processes and, therefore, the use of adhesive systems such as pulp capping materials must be viewed with caution due to its large cytotoxic effect when in close contact with the pulp.
\end{abstract}

\author{
'Department of Restorative \\ Dentistry, Endodontics and Dental \\ Materials, USP - Universidade de São \\ Paulo, Bauru, São Paulo, Brazil \\ ${ }^{2}$ Department of Biological Sciences, \\ Bauru School of Dentistry, USP \\ - Universidade de São Paulo, \\ Bauru, São Paulo, Brazil \\ ${ }^{3}$ Department of Restorative \\ Dentistry, School of Dentistry, \\ USP - Universidade de São \\ Paulo, Bauru, São Paulo, Brazil
}

Correspondence: Carlos Ferreira dos Santos, Al. Octávio Pinheiro Brizolla, 9-75, 17012-950 Bauru, SP, Brasil. Tel: +55-14- 3235-8295. e-mail: cfsantos@fob.usp.br

\section{Introduction}

The main purpose of restorative dentistry is to recover and maintain tooth health by means of adequate restorative treatment in order to protect and re-establish dental pulp function. Pulp plays an important role in the formation and nutrition of dentin as well as in the innervation and defense of the teeth (1).

Dental materials developed for restorative dentistry are under continuous reformulation in order to find compositions able to achieve the best results for both patient and dentist. However, the main challenge of dental materials industry lays on defining the precise combination of dentin-pulp complex protection materials and restorative ones. Restorative materials should meet some requirements such as achieving physical and mechanical properties in a similar pattern compared to dental structure and also being biocompatible. Considering the importance of maintenance of pulpal health, the effect of restorative materials placed in deep cavities should not be underestimated. An uncountable number of products and adhesive techniques are continuously developed, and the biological effects of the released substances on dental pulp cells is an issue that requires special attention by the dental community (2).

Some studies have shown that dental pulp fibroblasts can secret many types of cytokines in response to various stimuli in a similar manner to immune and endothelial cells as well as odontoblasts (3). Cytokines are proteins secreted by innate and adaptive immune cells that act stimulating these cells. Different cytokines are produced in response to microorganisms and other stimuli, such as dead cells, thus triggering several responses in immune and inflammatory cells. Among the cytokines, there is a group presenting structural homology that stimulates leukocyte migration from blood vessels to tissues. These molecules are known as chemokines (chemotactic cytokines), which are produced by many cell types in response to inflammatory stimuli. They are responsible for leukocytes recruitment to injured tissue areas. In addition, the cytokines of the CXC subfamily, such as IL-8, growth-related oncogene (GRO) and cell-derived stroma (SDF), are potent chemotactic and neutrophil activators (3). Some studies have shown that dental pulp fibroblasts are real sources of chemokines (1,3-5).

CXCL8, also called IL-8 is produced by a range of cell types, including neutrophils, monocytes, macrophages, fibroblasts, and keratinocytes. The release of CXCL8 occurs after cellular stimulation with microorganisms (LPS) and endogenous mediators such as IL-1. Its main function is to induce the migration of immunocompetent cells 
and primary effectors of inflammation, amplifying the inflammatory process considered a key factor of acute inflammatory disease. It has been shown that pulps affected by inflammation have higher amounts of CXCL8 than healthy pulps and that LPS-stimulated pulp fibroblasts also produce higher levels of CXCL8 than non-stimulated ones (6).

CXCL12 is a highly expressed chemokine under basal conditions, also known as SDF- $1 \alpha$, being considered constitutive and has been frequently related to the maintenance of tissue homeostasis. CXCL12 is particularly involved in neovascularization and mineralization, as well as in chemotaxis function (7). Its chemotactic function is exerted, in addition to neutrophils, on lymphocytes and monocytes and has the capacity to recruit CD34+ stem cells (8). The importance of CXCL12 in recruitment of stem cells and progenitors was established and showed that their expression in tissues affected by aggressions is correlated with recruitment of adult stem cells and tissue repair (9). However, during the inflammatory process CXCL12 expression may be decreased (10). In the case of dental pulps affected by inflammation, some studies have - reported increased expression of this chemokine and its receptor $(9,11,12)$. A discrete increase was observed in the production of CXCL12 in human dental pulp stimulated by heat-inactivated Enterococcus faecalis (13). Although there is a divergence in the production of CXCL12 in inflamed tissues, literature reports that fibroblasts are also sources of this chemokine $(10,14)$.

Inflammation of dental pulp is characterized by changes in blood flow, in the function of immunocompetent cells and in neuronal activity (15). Many mediators, including histamine, prostaglandins and neuropeptides, are involved in one or more of these processes, while all steps may involve nitric oxide (NO) $(16,17)$. NO is an intracellular messenger molecule with important cardiovascular, neurological and immune functions (16). NO has a role in non-specific immune responses, acting as a toxic agent in infections, and it is possible to confirm that one of the first potential activators of the inflammatory response is NO (16). Furthermore, other investigators reported that NO has an important role in the regulation of blood circulation of the pulp, describing its great involvement in the regulation of dental vascular homeostasis (18).

The biological compatibility of dental materials displays great importance to avoid or limit tissue irritation or degeneration of the dental pulp adjacent to the place where they are applied. The biocompatibility and cytotoxicity have been widely studied in different cell cultures or in deep cavities with or without pulp exposure $(2,19-21)$. However, the biological behavior of living cells, such as their immunomodulation by dental materials, is also an issue that requires investigation.

Despite the evidence of cytotoxicity of dental adhesives has been widely demonstrated by viability assays, it seems reasonable to investigate the effect of these substances on the functional state of surviving cells by means of the assessment of homeostatic and inflammatory mediators' release. To the best of our knowledge, the potential influence of adhesive components on the modulation of NO and the chemokines CXCL8 and CXCL12 in dental pulp cells is still lacking.

\section{Material and Methods \\ Culture of Dental Pulp Fibroblasts}

The experiments were conducted in accordance with the Declaration of Helsinki. Prior to experiments, ethical approval was obtained from the local Ethics Committee for Human Research of the Bauru School of Dentistry (protocol \#137/2007). Under patient informed consent, three third molars were donated from 3 distinct patients ( 1 male and 2 female subjects aged 18 - 25). Dental pulp was removed under aseptic conditions and tissues were minced for the achievement of fibroblasts cultures using an explant technique $(13,22,23)$. Fragments were incubated for cell outgrowth in Dulbecco's modified Eagle's medium (DMEM) (Gibco, Invitrogen Corporation, Carlsbad, CA,USA) supplemented with 10\% fetal bovine serum (Gibco) and antibiotics $(100 \mu \mathrm{g} / \mathrm{mL}$ penicillin, $100 \mu \mathrm{g} / \mathrm{mL}$ streptomycin, $0.5 \mathrm{mg} / \mathrm{mL}$ amphotericin B - Invitrogen Corporation). Cultures were kept at $37^{\circ} \mathrm{C}$ in a humidified atmosphere of $5 \% \mathrm{CO}_{2}$ and $95 \%$ air. Experiments were performed using sub cultured fibroblasts between the fourth and eighth passages. Phenotypic characterization of the dental pulp fibroblasts (DPF) was performed by a previous study by our group (22).

\section{Dental Materials Preparation}

HEMA (H) (2-hydroxy-ethyl-methacrylate) and Single Bond (SB) compound by HEMA, bis-GMA, ethyl alcohol, MDP, silanized silica, water, camphorquinone (3M ESPE, St. Paul, MN, USA) were tested in this study (11). Previously to cell stimulation, both materials were diluted in $10 \%$ FBS DMEM. HEMA concentrations were set at 10, 100 and $1,000 \mathrm{nM}(\mathrm{H} 10, \mathrm{H} 100, \mathrm{H} 1000$, respectively) while SB was 10 -fold serially diluted in culture medium $\left(10^{-4}, 10^{-3}\right.$ and $\left.10^{-2} \mathrm{v} / \mathrm{v}\right)$. Additionally, SB was prepared at a light cured form according to ISO 10993 guidelines at $86.39 \mathrm{~mm}^{2} / \mathrm{mL}$ of culture medium. For this purpose, aliquots were inserted into a round metal device designed for the production of discs measuring $5 \mathrm{~mm}$ width and $3 \mathrm{~mm}$ high and light cured according to the manufacturer's instructions in aseptic conditions. These specimens were placed into transwell inserts (Corning Incorporated, New York, NY, USA) (0.4 $\mu \mathrm{m}$ 
pore size) to avoid direct physical contact with the cells (20).

\section{Fibroblasts Stimulation}

DPF were seeded at $5 \times 10^{4}$ cells/well in 24-well plates. Confluent cells had the medium replaced by $1 \mathrm{~mL}$ of DMEM only or containing the diluted dental materials as described above. Transwell inserts alone or with set SB specimens were also placed over cells in DMEM. After 6 and $24 \mathrm{~h}$, supernatants were collected and stored at $-20^{\circ} \mathrm{C}$ after centrifugation. Cells were submitted to cytotoxicity test or collected by trypsinization or Trizol ${ }^{\circledR}$ (Invitrogen) accordingly. For each assay, experiments were conducted in triplicate.

\section{Cytotoxicity Assay}

After removal of supernatants and inserts, 20 $\mu \mathrm{L}$ of an MTT [3-(4,5-Dimethylthiazol-2-yl)-2,5diphenyltetrazolium bromide](Sigma-Aldrich) solution (5 $\mathrm{mg} / \mathrm{mL}$ ) in phosphate buffered saline (PBS) were added to the cells or cell-free blank wells followed by $180 \mu \mathrm{L}$ of 10\% FBS DMEM. Fibroblasts were incubated for $4 \mathrm{~h}$ at $37{ }^{\circ} \mathrm{C}$ at standard conditions. MT solution was then removed and replaced with $100 \mu \mathrm{L}$ of isopropanol. The plate was incubated for $20 \mathrm{~min}$ at room temperature and the optical density (OD) of the wells was determined using a plate reader (FLUOstar Optima, BMG Labtech, Ortenberg, Germany) at $570 \mathrm{~nm}$ wavelength.

\section{Trypan Blue Exclusion Test}

After stimulation, cells were detached, stained with 0.4\% Trypan Blue Solution (Sigma Aldrich) and counted with a hemocytometer. Dye exclusion test was based upon the concept that viable cells do not take up the impermeable dye.

\section{Nitric Oxide (NO) Measurement}

The Griess method was employed as previously described $(13,24)$. Released nitric oxide on DPF supernatants was measured based on nitrite $\left(\mathrm{NO}_{2}-\right)$ content, which in turn is one of the stable products of NO. Aliquots of $50 \mu \mathrm{L}$ of each cell supernatant were added to 96-well plate in duplicate. As negative control, 10\% FBS DMEM alone was tested and DMEM diluted substances (Single Bond and HEMA). $25 \mu \mathrm{L}$ of $2 \%$ sulfanilamide (SigmaAldrich) in 5\% phosphoric acid (Merck) were added to the wells and incubated for $10 \mathrm{~min}$. After that, $25 \mu \mathrm{L}$ of $0.2 \% \mathrm{~N}$-(1-naphthyl) ethylenediamine dihydrochloride (NED) (Sigma-Aldrich) in distilled water were added and samples were de novo incubated for $10 \mathrm{~min}$ protected from light. Finally, the absorbance was measured at 530 $\mathrm{nm}$. Calculation of nitrite concentration was performed based on the optical density of a two-fold serially diluted
$\mathrm{NaNO}_{2}$ solution (Sigma-Aldrich).

\section{Cytokines detection}

The production of CXCL12 (SDF-1) and CXCL8 (IL-8) was detected by means of enzyme-linked immunosorbent assay (ELISA) (REtD systems, Minneapolis, USA) according to the manufacturer's instructions. Briefly, capture antibodies were incubated with samples or standards followed by incubation with the respective biotinconjugated detection antibodies. Colorimetric reaction was observed by the presence of streptavidin-conjugated peroxidase and the added substrate. Absorbance was measured at $450 \mathrm{~nm}$ (4).

\section{Expression of Cytokines $m R N A$}

After removal of supernatants, DPF were collected with $1 \mathrm{~mL}$ of Trizol ${ }^{\circledR}$ (Invitrogen). Total RNA was isolated by guanidinium isothiocyanate-phenol-chloroform extraction. Briefly, homogenization, chloroform extraction, isopropanol precipitation, and 75\% ethanol $(\mathrm{v} / \mathrm{v})$ washing of precipitated RNA were performed. Total RNA was quantified in a spectrophotometer (Nanodrop ${ }^{\circledR}$, Thermo Scientific, Wilmington, DE, USA) at the wavelengths of 280 and $260 \mathrm{~nm}$ and $1 \mu \mathrm{g}$ of total RNA was incubated with gDNAse Wipeout Buffer (Qiagen, Germantown, MD, USA) for 2 min at 42oC. Next, reverse transcription was performed using QuantiTect Reverse Transcription Kit (Qiagen) following the manufacturer's instructions. Synthetic cDNAs served as the templates for targets amplification by means of quantitative polymerase chain reaction (qPCR), which was performed with Taqman ${ }^{\circledR}$ Gene Expression Mastermix (Life Technologies, USA) (2x), Taqman ${ }^{\circledR}$ assays (20x) (Collagen I: Hs01028970_m1, CXCL12 (SDF-1): Hs00171022_m1, and CXCL8 (IL-8): Hs00174103) as the corresponding primers and probes, template cDNA and water. Amplifications were performed under the manufacturer's recommended conditions. Data were normalized based on an endogenous control (RPL13A, F:5'-CCGCTCTGGACCGTCTCAA-3', R: 5'-CCTGGTACTTCCAGCCAACCT-3', Probe:5'- (VIC)TGACGGCATCCCACCGCCCT-(TAMRA)-3 $(4,5,25)$ and analyzed in comparison to a sample from control group (DMEM only).

\section{Statistical Analysis}

Statistical analysis was performed using Graph Pad Prism 5.0 (GraphPad Software, La Jolla, CA, USA). Kolmogorov-Smirnov and Shapiro-Wilk tests were made to test the normality sample. Once all the groups had normal distribution, statistically significant differences were determined by one-way ANOVA followed by the Tukey post test for materials independently of the time and two-way 
ANOVA followed by the Bonferroni correction test for the comparisons between materials and experimental time.

The significance level was set at $p<0.05$.

\section{Results}

Cell viability of cultured human dental pulp fibroblasts in contact with diluted HEMA $(\mathrm{H} 10, \mathrm{H} 100$ and $\mathrm{H} 1000$ ) and Single Bond $\left(\mathrm{SB} 10^{-4}, \mathrm{SB} 10^{-3}\right.$ and $\left.\mathrm{SB} 10^{-2}\right)$ for 6 and $24 \mathrm{~h}$ is shown in Figure 1. Single Bond, in the concentration of 1:100 (SB 10-2), caused cell death in a higher proportion than the other tested materials based on Trypan Blue assay (Fig. 1). Less than $50 \%$ of viable cells were found in the experimental period of $6 \mathrm{~h}$. The same material caused a slight decrease on cell metabolism in the same period of time, as observed by MTT test. The results were more robust at $24 \mathrm{~h}$ since SB $10^{-2}$ decreased the percentage of viable cells $\dot{x}$ to $5 \%$. Cell metabolism, for the same period, decreased considerably (more than $70 \%)$. In contrast, the same result was not observed when the adhesive system was polymerized before subjected to the tests, thus suggesting that the cytotoxic effects decreased due to the reduction of non-reacted components.

None of the tested substances was able to alter significantly the NO release at the experimental conditions (Fig. 2). On the other hand, constitutive production of CXCL12 was significantly decreased at $6 \mathrm{~h}$ by the three tested dilutions of HEMA (Fig. 3). Interestingly, gene expression for this chemokine remained unaltered at the same conditions (Fig. 3).

B compared to CL $24 \mathrm{~h}$.
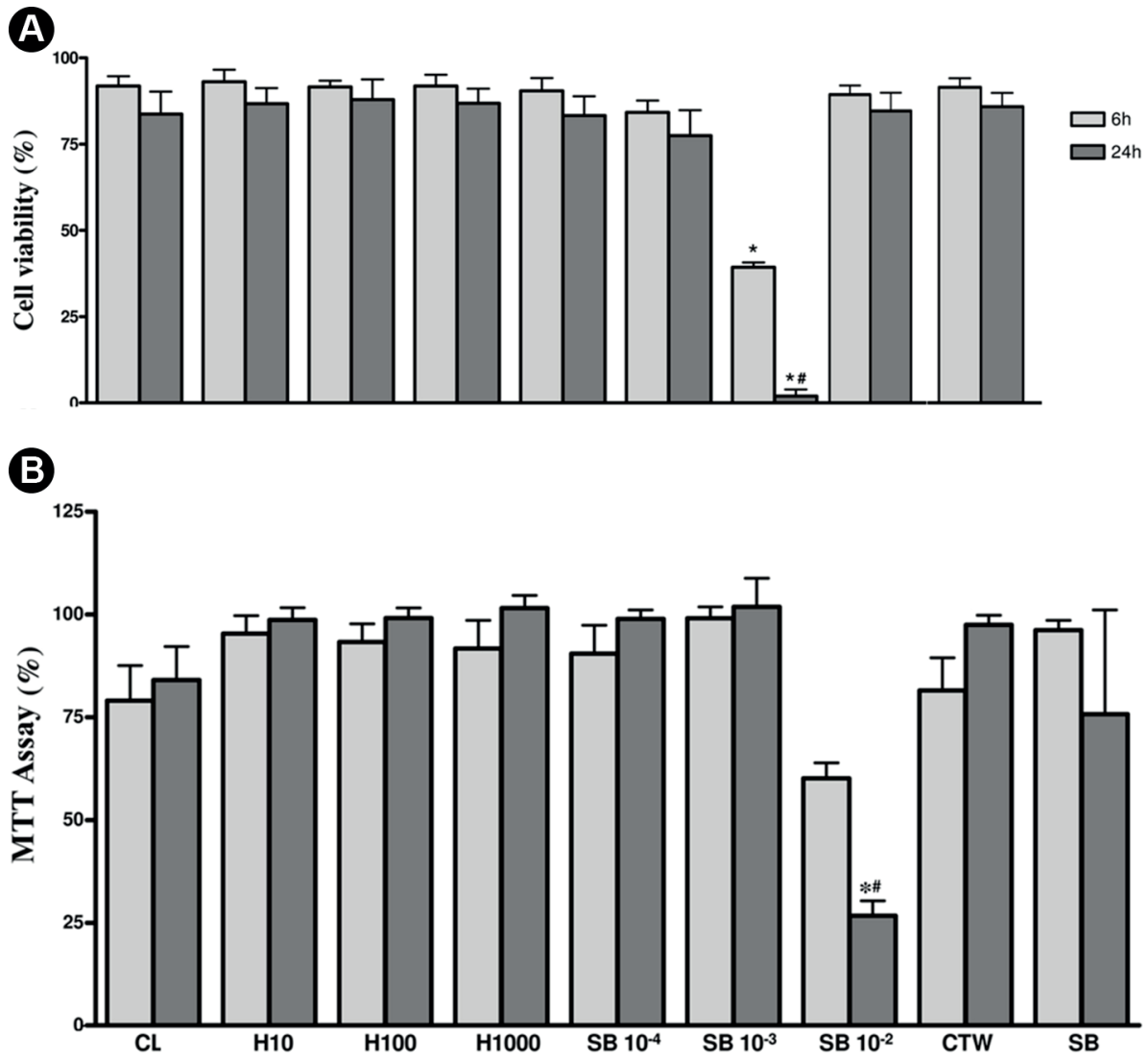

Figure 1: Cell viability and metabolic activity of cultured human dental pulp fibroblasts in contact with diluted HEMA (H10, H100 and H1000), Single Bond (SB10 ${ }^{-4}, \mathrm{SB}_{10}^{-3}$ and SB10 ${ }^{-2}$ ), medium + transwell membranes (CTW) or medium alone (CL). Data representative of mean and standard error for Trypan blue exclusion (A) and MTT assay at 6 and 24 h. ${ }^{*} \mathrm{p}<0.05$ in comparison to CL $6 \mathrm{~h}$ and \#p $<0.05$

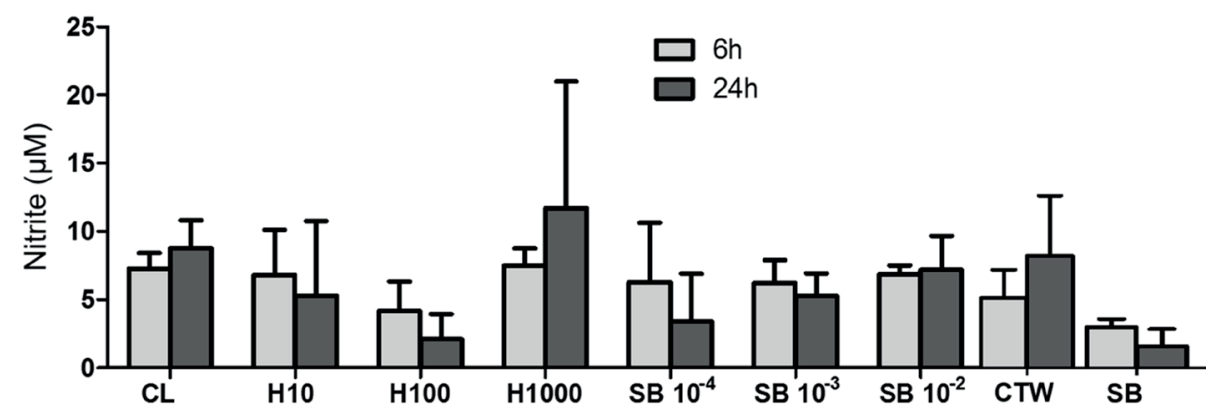

Figure 2: Nitric oxide released $(\mu \mathrm{M})$ by cultured human dental pulp fibroblasts in contact with diluted HEMA (H10, H100 and H1000), Single Bond (SB10-4, SB $10^{-3}$ and SB10 ${ }^{-2}$ ), medium + transwell membranes (CTW) or medium alone (CL). Nitrite content was detected at cell supernatants by Griess method. Data representative of mean and standard error at 6 and $24 \mathrm{~h}$. 
and repeatable method to assess the biocompatibility of dental materials. There are several in vitro test models to verify the cytotoxicity of biomaterials such as direct/ indirect contact tests or extract tests $(2,19,21)$. The present study aimed to compare the cytotoxicity and production of cytokines in dental pulp fibroblasts when exposed to different concentrations of the monomer HEMA and the adhesive system Single Bond (3M ESPE) by means of a direct/indirect contact test in vitro. Initially, Trypan Blue exclusion test and mitochondrial activity assessed by means of MTT assay were used to analyze the cell viability. The Griess method was employed to detect nitric oxide release. Reverse transcription (RT) followed by $\mathrm{qPCR}$ analysis and ELISA were performed in order to detect the mRNA expression and release of cytokines, respectively, by living remaining cells.

Trypan Blue test showed significant decrease in cell viability only for $\mathrm{SB}^{-2} 0^{-2}$ for both experimental periods, leading to almost complete cell death at $24 \mathrm{~h}$. No statistically significant differences were observed in cell viability for the other SB dilutions and for HEMA either. Interestingly, cell viability remained undisturbed by polymerized SB at both experimental periods. Similar results were observed for mitochondrial activity as shown by MTT assay (Fig. 1). However, this analysis showed significant decrease only for $\mathrm{SB}^{-2} 0^{-2}$ at $24 \mathrm{~h}$ of contact with cells. These findings can be confirmed by Mantellini et al. (20), who showed dramatic differences in the responses of the cells to three polymerization conditions (light curing for 0,10 or $40 \mathrm{~s}$ ). While unpolymerized and partially polymerized adhesive resin induced apoptosis very rapidly in macrophages, undifferentiated pulp cells (OD-21) and mouse odontoblastlike cells (MDPC-23), polymerized adhesive resin induced significant apoptosis only in macrophages.

Chen et al. (26) also reported increased cytotoxic effects of bonding agents on pulpal cells at higher concentrations after $24 \mathrm{~h}$ of incubation. The monomers bisphenol A-diglycidyl dimethacrylate (BisGMA), urethane dimethacrylate (UDMA), triethylene-glycoldimethacrylate (TEGDMA) and 2-hydroxy-ethylmethacrylate (HEMA) are commonly used constituents of adhesive systems and are cytotoxic when in direct contact with fibroblasts (1). HEMA, in a concentration ranging from 30 to $55 \%$, is one of the most common components of dentinadhesive systems. Studies suggest that because of its low molecular weight and its relative hydrophilic property, HEMA can diffuse through the dentin and reach the pulp, thus affecting odontoblasts viability and, in consequence, altering pulp physiology (21). At the clinical practice, unreacted monomers can penetrate the pulp chamber and reach the pulp cells by diffusion through dentin $(11,19)$

Bondingagentswerefound to release camphoroquinone, a photoinitiator and photosensitizer widely used to generate free radicals
Figure 3: Detection of CXCL12 protein levels (A) $(\mathrm{pg} / \mathrm{mL})$ or mRNA expression (B) at cultured human dental pulp fibroblasts in contact with diluted HEMA (H10, H100 and H1000), Single Bond (SB10-4, $\mathrm{SB} 10^{-3}$ and $\mathrm{SB}_{10}{ }^{-2}$ ) medium + transwell membranes (CTW) or medium alone (CL). Data representative of mean and standard error at 6 and 24 h. ${ }^{*} \mathrm{p}<0.05$ in comparison to CL $6 \mathrm{~h}$. 
including reactive oxygen. It has been documented that camphoroquinone acts not only as a cytotoxic agent, but also as a mutagen, and its lixiviation may partly explain why these resinous products are considered toxic agents (27).

Evidence shows that resin monomers conversion is usually incomplete. Besides the oxygen-inhibited layer preventing complete polymerization, free radicals can react with themselves or other radicals resulting in inactive products (28) and the unreacted monomers can reach the pulp tissue $(29,30)$. Literature reports that monomers such as HEMA are soluble in aqueous medium (31) and are present in adhesive systems such as Single Bond (11). However, under the conditions of the present study, HEMA did not alter the cell viability or metabolism even in direct contact with human dental pulp fibroblasts at $1 \mathrm{nM}$, in contrast with other works that report decrease of fibroblast grow in HEMA treatment groups ( $5 \mathrm{mmol} / \mathrm{L}$ and and $3 \mathrm{mmol} / \mathrm{L}$ ) compared to control group (32). The concentrations tested in the present study do not necessarily correspond to the ones present in resin systems, since these data are unavailable from manufacturer's information.

The production and the expression of CXCL12 was verified and the results showed that human dental pulp fibroblasts produced and expressed this protein constitutively, thus corroborating previous reports $(4,7,22)$. The presence of CXCL12 in basal conditions in connective tissues favors the permanence of immature dendritic cells responsible for the link between innate and adaptive immunity (33). This basal production can also play an important role in maintaining tissue homeostasis through the retention of hematopoietic stem cells in connective tissues $(34,35)$.

There is a disagreement in the literature regarding the expression of CXCL12 under inflammatory conditions. While some studies have reported a decrease in the expression during the inflammatory process (10), others describe increased expression of this chemokine and its receptor (12). Previous studies by our group demonstrated decrease in CXCL12 production by DPF under stimulation with LPS and lipoteichoic acid $(\mathrm{LTA})(4,22)$.

CXCL12 production by DPF decreased under the three concentrations of monomer HEMA (10 nM, $100 \mathrm{nM}$ and $1000 \mathrm{nM}$ ) at $6 \mathrm{~h}$. One can suggest that the protein levels decreased due to the reduction in mRNA expression before the experimental period of $6 \mathrm{~h}$. Another factor that must be considered is the possible occurrence of post-translational regulation of the protein production or degradation as indirect consequence to the stimulus. Besides induction of cytokine synthesis, inflammatory stimuli might also lead to increased production of metalloproteinases (MMPs) by fibroblasts (36). Proteins of the tissue extracellular matrix are not the only substrates of these enzymes. The chemokine CXCL12 is a substrate of various MMPs, such as MMP-1, $-2,-3,-9,-13$ and -14 and these enzymes are able to inactivate this chemokine, compromising its binding to the corresponding receptor. Although cell viability and metabolism were not affected by HEMA, the production
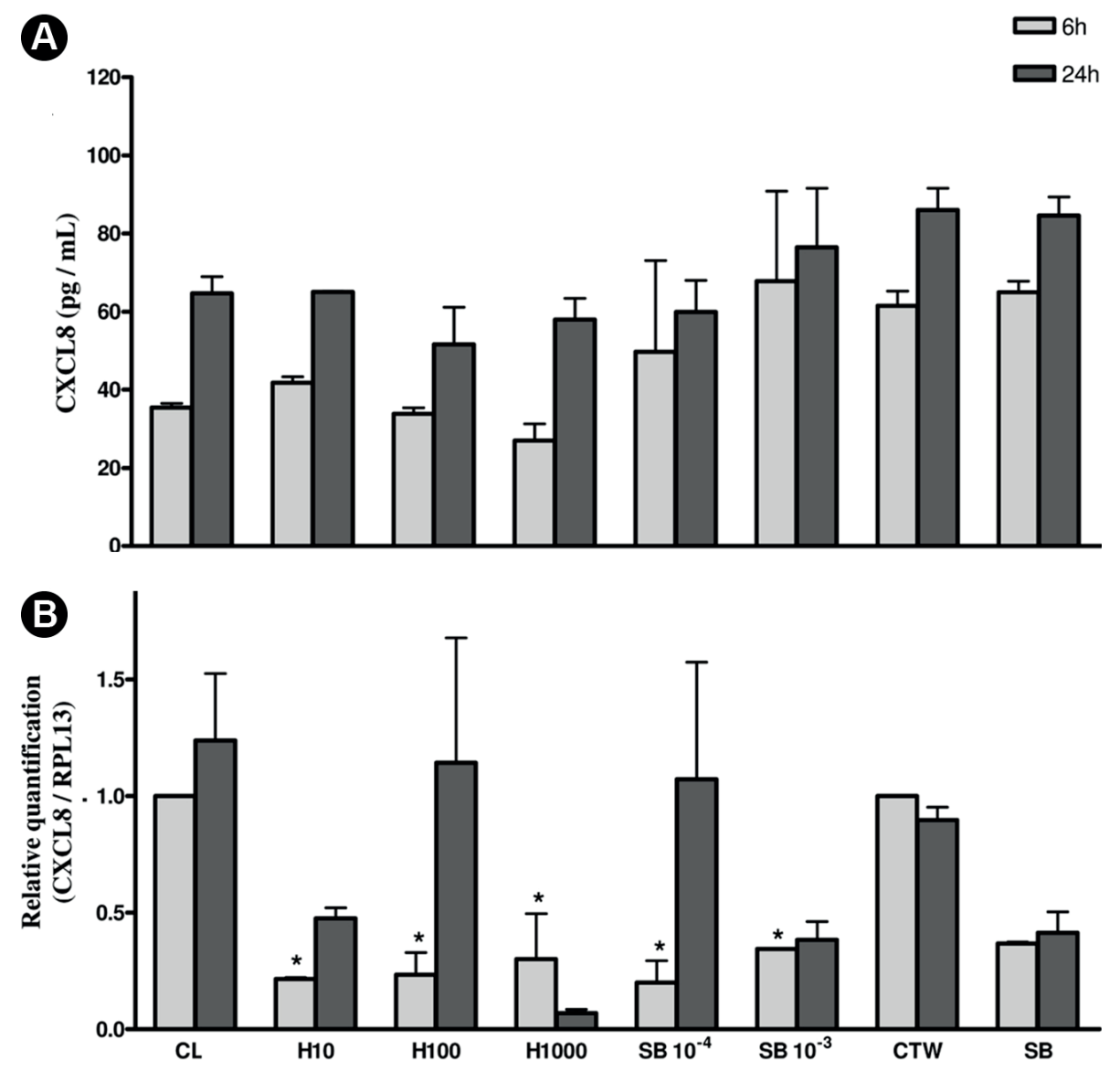

Figure 4: Detection of CXCL8 protein levels (A) $(\mathrm{pg} / \mathrm{mL})$ or mRNA expression (B) at cultured human dental pulp fibroblasts in contact with diluted HEMA (H10, H100 and H1000), Single Bond (SB10-4, $\mathrm{SB} 10^{-3}$ and $\mathrm{SB}_{10}{ }^{-2}$ ) medium + transwell membranes (CTW) or medium alone (CL). Data representative of mean and standard error at 6 and 24 h. ${ }^{*} \mathrm{p}<0.05$ in comparison to CL $6 \mathrm{~h}$. 
of CXCL12 was significantly decreased under the monomer presence. These data suggest that this material might affect the dental pulp cells homeostasis by disturbing CXCL12 constitutive production.

Gene expression for CXCL8 by dental pulp fibroblasts decreased under stimulation with all tested materials except for polymerized SB $\left(\mathrm{H} 10, \mathrm{H} 100\right.$ and $\mathrm{H} 1000$ and SB $10^{-4}$ and $\left.10^{-3}\right)$ at $6 \mathrm{~h}$. However, protein levels of CXCL8 remained unaltered by the materials. One may speculate that the gene expression alteration induced by the chemicals was not enough to alter the cytokine levels present in the cell supernatant at the experimental conditions tested. Despite that, it is reasonable to suggest once again that HEMA and Single Bond might alter the cellular homeostasis even not affecting cellular viability.

NO has received much attention since the discovery of its functions. It has high reactivity and short half-life ranging from 3 to $60 \mathrm{~s}$, is rapidly destroyed by oxygen, and its oxidation produces nitrite and nitrate (13). This can be a determining factor for the results obtained in the present work. New studies with analysis time shorter than 6 hours may be necessary to effectively observe the performance of the materials evaluated in current study.

Under clinical conditions, in vivo studies have demonstrated that the application of an adhesive resin directly onto a site of pulp exposure or to a thin layer of dentin (less than $0.5 \mathrm{~mm}$ ) causes dilation and congestion of blood vessels as well as chronic inflammatory pulpal response (37), most likely a consequence of cell necrosis and not a direct action of monomer on cells with immune function. Immune system is the main responsible for dental pulp response to aggressive substances leading to the production of inflammatory mediators. Resident cells such as fibroblasts are able to recognize bacterial byproducts such as lipopolysaccharide and dead cells. Innate immune receptors usually recognize endogenous molecules released from cells under stress or as a consequence of necrosis known as Damage Associated Molecular Patterns (DAMPs) or alarmins. Some of these molecules are the High Mobility Group Box Protein 1 (HMGB1), IL-1 $\alpha$, IL33 and mitochondrial DNA. Cellular recognition of these components results in proinflammatory effects including modulation of cytokines release and nitric oxide production $(38,39)$. The induction of DAMPs release by HEMA and unpolymerized $\mathrm{SB}$ as a possible role for the alterations in protein levels of CXCL12 and gene expression of CXCL8 is an issue that requires further investigations.

Single Bond and HEMA at various concentrations, decreased expression and production of molecules involved in inflammatory processes and, therefore, the use of adhesive systems such as pulp capping material must be viewed with caution due to its large cytotoxic effect when in close contact with the pulp organ.

\section{Resumo}

Este estudo avaliou in vitro a viabilidade e metabolismo celular, liberação de óxido nítrico e produção de quimiocinas em cultura de fibroblastos de polpa dental humana (DPF) em contato com HEMA e Single Bond. Culturas de DPF foram estabelecidas por meio de uma técnica de explante. Uma vez plaqueadas, as células foram mantidas em contato com concentrações crescentes de HEMA (10, 100 e 1000 nM) ou Single Bond (SB) [10 vezes diluidas em série em meio de cultura $\left(10^{-4}, 10^{-3}\right.$ e $10^{-2}$ $\mathrm{v} / \mathrm{v})]$ e também com SB polimerizado. A citotoxicidade foi avaliada pelo método de exclusão de Trypan Blue e pelo ensaio de 3-(4,5-dimetiltiazol2-il)-2,5-difeniltetrazólio brometo (MT). A liberação de óxido nítrico no sobrenadante celular foi detectada pelo método de Griess, enquanto as quimiocinas (CXCL12 e CXCL8) foram detectadas por ELISA. RT-qPCR foi empregada para análise de expressão gênica de quimiocinas. Testes citotóxicos mostraram diferenças significativas para SB $10^{-2}$. Nenhum dos materiais testados alterou significativamente os níveis de NO. Os níveis de proteina de CXCL12 foram significativamente diminuidos apenas pelo HEMA. Por outro lado, enquanto o RNAm de CXCL12 permaneceu inalterado, a expressão gênica de CXCL8 teve redução significativa com todos os materiais, com exceção do SB polimerizado. Em conclusão, Single Bond e HEMA, em várias concentrações, diminuíram a expressão e produção de moléculas envolvidas em processos inflamatórios e, portanto, o uso de sistemas adesivos, como o material protetor da polpa, deve ser visto com cautela devido ao seu grande efeito citotóxico quando em contato com a polpa.

\section{Acknowledgements}

This study was funded by FAPESP (Grants 2005/60167-0 and 2010/012301 to CFS). This study was financed in part by the Coordenação de Aperfeiçoamento de Pessoal de Nivel Superior - Brasil (CAPES) - Finance Code 001

\section{References}

1. Modena KC, Casas-Apayco LC, Atta MT, Costa CA, Hebling J, Sipert $\mathrm{CR}$, et al. Cytotoxicity and biocompatibility of direct and indirect pulp capping materials. J Appl Oral Sci 2009;17:544-554.

2. de Souza Costa CA, Hebling J, Scheffel DL, Soares DG, Basso FG, Ribeiro AP. Methods to evaluate and strategies to improve the biocompatibility of dental materials and operative techniques. Dent Mater 2014;30:769-784.

3. Le Clerc J, Tricot-Doleux S, Pellen-Mussi P, Perard M, Jeanne S, Perez F. Expression of factors involved in dental pulp physiopathological processes by nemotic human pulpal fibroblasts. Int Endod J 2018;51 Suppl 2:e94-e106.

4. Sipert $C R$, Morandini AC, Dionisio TJ, Machado MA, Oliveira SH, Campanelli $\mathrm{AP}$, et al. In vitro regulation of CCL3 and CXCL12 by bacterial by-products is dependent on site of origin of human oral fibroblasts. J Endod 2014;40:95-100.

5. Azevedo FP, Morandini AC, Sipert CR, Dionisio TJ, Santos CF, Damante $\mathrm{CA}$, et al. Palatal mucosa derived fibroblasts present an adaptive behavior regarding cytokine secretion when grafted onto the gingival margin. BMC Oral Health 2014;14:21.

6. Silva AC, Faria MR, Fontes A, Campos MS, Cavalcanti BN. Interleukin-1 beta and interleukin- 8 in healthy and inflamed dental pulps. J Appl Oral Sci 2009;17:527-532.

7. Yang J, Yuan G, Chen Z. Pulp Regeneration: current approaches and future challenges. Front Physiol 2016;7:58.

8. Karin N. The multiple faces of CXCL12 (SDF-1alpha) in the regulation of immunity during health and disease. J Leukoc Biol 2010;88:463-473.

9. Jiang $L, Z h u Y Q, D u R$, Gu YX, Xia L, Qin F, et al. The expression and role of stromal cell-derived factor-1alpha-CXCR4 axis in human dental pulp. J Endod 2008;34:939-944.

10. Hosokawa Y, Hosokawa I, Ozaki K, Nakae H, Murakami K, Miyake Y, 
et al. CXCL12 and CXCR4 expression by human gingival fibroblasts in periodontal disease. Clin Exp Immunol 2005;141:467-474.

11. Jiang RD, Lin $H$, Zheng G, Zhang XM, Du O, Yang M. In vitro dentin barrier cytotoxicity testing of some dental restorative materials. J Dent 2017;58:28-33.

12. Jiang HW, Ling JQ, Gong QM. The expression of stromal cellderived factor 1 (SDF-1) in inflamed human dental pulp. J Endod 2008;34:1351-1354.

13. Sipert CR, Moraes IG, Bernardinelli N, Garcia RB, Bramante CM, Gasparoto $\mathrm{TH}$, et al. Heat-killed Enterococcus faecalis alters nitric oxide and CXCL12 production but not CXCL8 and CCL3 production by cultured human dental pulp fibroblasts. J Endod 2010;36:91-94.

14. Diaz-Araya G, Vivar R, Humeres C, Boza P, Bolivar S, Munoz C. Cardiac fibroblasts as sentinel cells in cardiac tissue: Receptors, signaling pathways and cellular functions. Pharmacol Res 2015;101:30-40.

15. Olgart L, Edwall L, Gazelius B. Involvement of afferent nerves in pulpal blood-flow reactions in response to clinical and experimental procedures in the cat. Arch Oral Biol 1991;36:575-581.

16. Sterin-Borda L, Furlan C, Reina S, Orman B, Borda E. Differential signalling pathways involved in cholinoceptor-dependent stimulation of nitric oxide isoforms in dental pulp. Int Endod J 2007;40:544-552.

17. Le Clerc J, Perard M, Pellen-Mussi P, Novella A, Tricot-Doleux S, Jeanne $S$, et al. Characterization of a programmed necrosis process in 3-dimensional cultures of dental pulp fibroblasts. Int Endod J 2013;46:308-316.

18. Olgart L, Kostouros GD, Edwall L. Local actions of acetylcholine on vasomotor regulation in rat incisor pulp. Acta Physiol Scand 1996;158:311-316.

19. de Souza Costa CA, Teixeira HM, Lopes do Nascimento AB, Hebling J. Biocompatibility of resin-based dental materials applied as liners in deep cavities prepared in human teeth. J Biomed Mater Res B Appl Biomater 2007;81:175-184.

20. Mantellini MG, Botero TM, Yaman P, Dennison JB, Hanks CT, Nor JE. Adhesive resin induces apoptosis and cell-cycle arrest of pulp cells. J Dent Res 2003;82:592-596.

21. Lanza CR, de Souza Costa CA, Furlan M, Alecio A, Hebling J. Transdentinal diffusion and cytotoxicity of self-etching adhesive systems. Cell Biol Toxicol 2009;25:533-543.

22. Sipert CR, Morandini AC, Modena KC, Dionisio TJ, Machado MA, Oliveira SH, et al. CCL3 and CXCL12 production in vitro by dental pulp fibroblasts from permanent and deciduous teeth stimulated by Porphyromonas gingivalis LPS. J Appl Oral Sci 2013;21:99-105.

23. Morandini AC, Sipert CR, Gasparoto TH, Greghi SL, Passanezi E, Rezende $M L$, et al. Differential production of macrophage inflammatory protein-1alpha, stromal-derived factor-1, and IL- 6 by human cultured periodontal ligament and gingival fibroblasts challenged with lipopolysaccharide from P. gingivalis. J Periodontol 2010;81:310-317.

24. Morandini AC, Sipert CR, Ramos-Junior ES, Brozoski DT, Santos CF.
Periodontal ligament and gingival fibroblasts participate in the production of TGF-beta, interleukin (IL)-8 and IL-10. Braz Oral Res 2011;25:157-162.

25. Palmqvist $P$, Lundberg $P$, Lundgren I, Hanstrom L, Lerner UH. IL-1beta and TNF-alpha regulate IL-6-type cytokines in gingival fibroblasts. J Dent Res 2008;87:558-563.

26. Chen RS, Liu CC, Tseng WY, Jeng JH, Lin CP. Cytotoxicity of three dentin bonding agents on human dental pulp cells. J Dent 2003;31:223-229.

27. Huang FM, Chang YC. Cytotoxicity of dentine-bonding agents on human pulp cells in vitro. Int Endod J 2002;35:905-909.

28. Shawkat ES, Shortall AC, Addison 0, Palin WM. Oxygen inhibition and incremental layer bond strengths of resin composites. Dent Mater 2009;25:1338-1346.

29. Pashley $\mathrm{DH}$. Consideration of dentine permeability in cytotoxicity testing. Int Endod J 1988;21:143-154.

30. Hanks CT, Wataha JC, Parsell RR, Strawn SE, Fat JC. Permeability of biological and synthetic molecules through dentine. J Oral Rehabil 1994;21:475-487.

31. Geurtsen W, Lehmann F, Spahl W, Leyhausen G. Cytotoxicity of 35 dental resin composite monomers/additives in permanent 3T3 and three human primary fibroblast cultures. J Biomed Mater Res 1998;41:474-480.

32. Kurata $\mathrm{S}$, Morishita $\mathrm{K}$, Kawase $\mathrm{T}$, Umemoto K. Cytotoxic effects of acrylic acid, methacrylic acid, their corresponding saturated carboxylic acids, HEMA, and hydroquinone on fibroblasts derived from human pulp. Dent Mater J 2012;31:219-225.

33. Ricart BG, John B, Lee D, Hunter CA, Hammer DA. Dendritic cells distinguish individual chemokine signals through CCR7 and CXCR4. J Immunol 2011;186:53-61.

34. Hebling J, Giro EM, Costa CA. Biocompatibility of an adhesive system applied to exposed human dental pulp. J Endod 1999;25:676-682.

35. Gwinnett AJ, Tay F. Early and intermediate time response of the dental pulp to an acid etch technique in vivo. Am J Dent 1998;11 Spec No:S3544.

36. Wisithphrom $K$, Murray PE, Windsor $\amalg$. Interleukin-1 alpha alters the expression of matrix metalloproteinases and collagen degradation by pulp fibroblasts. J Endod 2006;32:186-92.

37. Tsai $\mathrm{CH}$, Chen YJ, Huang FM, Su YF, Chang YC. The upregulation of matrix metalloproteinase-9 in inflamed human dental pulps. J Endod 2005;31:860-862.

38. Mencin A, Kluwe J, Schwabe RF. Toll-like receptors as targets in chronic liver diseases. Gut 2009;58:704-720.

39. Hirsiger S, Simmen HP, Werner CM, Wanner GA, Rittirsch D. Danger signals activating the immune response after trauma. Mediators Inflamm 2012;2012:315941.
Received August 18, 2018 Accepted October 29, 2018 